\title{
Analysis of Stand-up Paddle Boarding: A systematic review Análisis del Stand Up Paddle. Una revisión sistemática
}

\author{
Arkaitz Castañeda-Babarro, Eneko Balerdi, Patxi León-Guereño \\ Universidad de Deusto (Spain)
}

\begin{abstract}
Stand-up paddle boarding (SUP) is a relatively new physical activity, which involves paddling with a single- blade paddle while standing on a surf-like board. Although its practice has increased in recent years, there has not been much research into this sport. The aim of this review is to analyse the research carried out so far in SUP, for which purpose the following databases have been consulted: PUBMED/MEDLINE, Web of Science (WOS), Cochrane library, Google scholar and Scopus, using the following search phrase base (Stand up paddle [Title/Abstract]) OR (Stand-up paddle [Title/Abstract]). 182 articles in total were obtained and after applying the PRISMA method, 36 articles were included, divided into 5 groups: physiology, biomechanics, injury, education and others. Existing literature shows the great potential of this activity in improving health-related parameters such as cardiovascular system or balance, as well as describing a balanced mesomorph somatotype and a good cardiovascular level in elite paddlers. On the other hand, a higher injury rate has been recorded in shoulders, lower back and elbows in SUP race participants and in the lower body in the case of SUP surfing, with strength training being the training variable that is most closely linked to injury prevention. This review demonstrates that SUP is an activity with great potential for application in education, as well as health improvement.
\end{abstract}

Key words: SUP, Stand-up paddle boarding, physiology, biomechanics, injuries, education.

Resumen: El Stand Up Paddle (SUP) es una actividad física relativamente nueva, que implica remar con un remo de una sola hoja mientras se está de pie sobre una tabla similar a la del surf. Aunque su práctica ha aumentado en los últimos años, no hay mucha investigación sobre este deporte. El objetivo de esta revisión es analizar la investigación realizada hasta el momento. Se han consultado las siguientes bases de datos: PUBMED/MEDLINE, Web of Science (WOS), biblioteca Cochrane, Google Scholar y Scopus, utilizando la siguiente base de frases de búsqueda (Stand up paddle [Título / Resumen]) O (Stand-up paddle [Título /Resumen]). Se obtuvieron un total de 182 artículos y tras aplicar el método PRISMA se incluyeron un total de 36 artículos, divididos en 5 grupos: fisiología, biomecánica, lesión, educación y otros. La literatura existente muestra el gran potencial de esta actividad para la mejora de parámetros relacionados con la salud, como el sistema cardiovascular o el equilibrio, además de describir un somatotipo mesomorfo equilibrado y un buen nivel cardiovascular en palistas de élite. También se ha registrado una mayor tasa de lesiones en hombros, espalda baja y codos para los participantes de la carrera de SUP y en la parte inferior del cuerpo para el SUP surf, siendo el entrenamiento de fuerza la variable de entrenamiento con mayor relación con la prevención de lesiones. Esta revisión demuestra que el SUP es una actividad con gran potencial de aplicación en la educación, así como para la mejora de la salud.

Palabras clave: SUP, Stand-up paddleboarding, fisiología, biomecánica, lesiones, educación.

\section{Introduction}

Stand-up paddle boarding (SUP) is a relatively new sport, as well as a recreational activity, in which the practitioner uses a paddle to move through the water while standing on a surfboard. SUP as a sport has its origins in the Hawaiian Islands where it is also known by its Hawaiian name Ku Hoe He'e Nalu (Argyle, M., 2011). Despite coming into being in the 1960s, its «renaissance» was during the non-wave period in the early 2000s when surfers used large stand-up paddle

Fecha recepción: 14-05-21. Fecha de aceptación: 19-10-21

Arkaitz Castañeda-Babarro

arkaitz.castaneda@deusto.es boards as a means of maintaining fitness and sea skills (Addison, 2010). People became interested, and from there, the first official SUP championship was held in 2004 (Beachboy, 2006). The first edition of the SUP and International Surfing Association (ISA) World Championships was held in 2012 in Peru following institutional recognition by the ISA earlier that year (ISA, 2021).

Its popularity has increased worldwide, probably due to the health and strength benefits it offers (S, 2011). In fact, about a decade ago, it was the fastest growing water sport in the world (Stand Up Paddle Industry Association, 2014). Schram, Hing, \& Climstein (2016a) commented that the reasons for this large, rapid growth in SUP participation, apart from being considered very dynamic and easy to learn, may be because it does not require 
complicated techniques and offers great health benefits.

There have been several cases of research into SUP, with several disciplines having studied this type of sport based on knowledge about them. Investigations that have focused especially on physiological variables (somatotype, health benefits, efficiency...), biomechanics (paddling technique, muscle activation...), incidence and aetiology of injury (types of injuries, frequency...), applications in teaching and other topics. For instance, this practical report will focus on specific SUP updated knowledge and will attempt to provide useful information for coaches, physiologists and team physician members. As such, it aims to show what has been done in SUP, offering an overview and thus highlighting the gaps in literature, and facilitating future research into this sport.

\section{Method}

This article is a review of existing studies involving SUP. Research was conducted in accordance with a preferred item subject to review (PRISMA) guidelines (Moher D., Liberati A., Tetzlaff J., Altman D.G. \& The PRISMA Group (2009); Stewart, Clarke, Rovers, Riley, Simmonds, Stewart, 2015), which enabled the review's integrity to be better enhanced.

The following databases were used to carry out a structured search: PUBMED/MEDLINE, Web of Science (WOS), Cochrane library, Google academic and Scopus. Proper bibliographic support was assured with these databases, and the search was completed without being confined to any specific years, with results being included up to 24th March 2021 inclusive. Search terms covered a range of Medical Subject Headings $(\mathrm{MeSH})$ and freetext words for key concepts associated with both WAnT and performance, with the following unique search equation: Search terms covered a range of free-text words for key concepts associated with either SUP, with the following unique search equation: (Stand up paddle [Title/Abstract]) OR (Stand-up paddle[Title/Abstract]). Articles deemed to be of relevance in this sphere of activity were obtained via the snowball strategy linked to this equation. Additionally, any relevant studies were found by screening article titles and abstracts from databases and bibliographic search results, and this was then complemented by a full-text review of all articles deemed to be of potential relevance, with their adherence to inclusion criteria being subject to final analysis. Furthermore, the reference sections of all the articles found were then scrutinized, with all titles and abstracts obtained being cross-referenced in order to pinpoint any duplicates or any perceived lack of actual studies on the subject.

With regard to inclusion and exclusion criteria, all articles containing the words «Stand up paddle» in the name or in the abstract of the article, irrespective of their discipline, were included. All articles were also included in the review regardless of the language in which they were written. In order for the text to be considered for inclusion, it was essential that it be published in a scientific journal, with the exclusion criteria applied being: 1) the articles found had to be directly related to the sport, 2) abstracts, papers presented at conferences or books were not included.

\section{Results}

Figure 1 shows that, from 182 articles related to the selected descriptors that were identified in the course of the literature search, only 36 met all the inclusion criteria for the purposes of the systematic review (Figure 1). Of these 182 articles, 55 were eliminated as duplicates, of the remaining 127 articles, 44 were eliminated following examination of the titles or abstracts, and of the 83 full-text articles assessed for eligibility, a further 47 papers were discarded because they were abstracts, conferences or books published on the topic. Thus, the current systematic review included 36 studies.

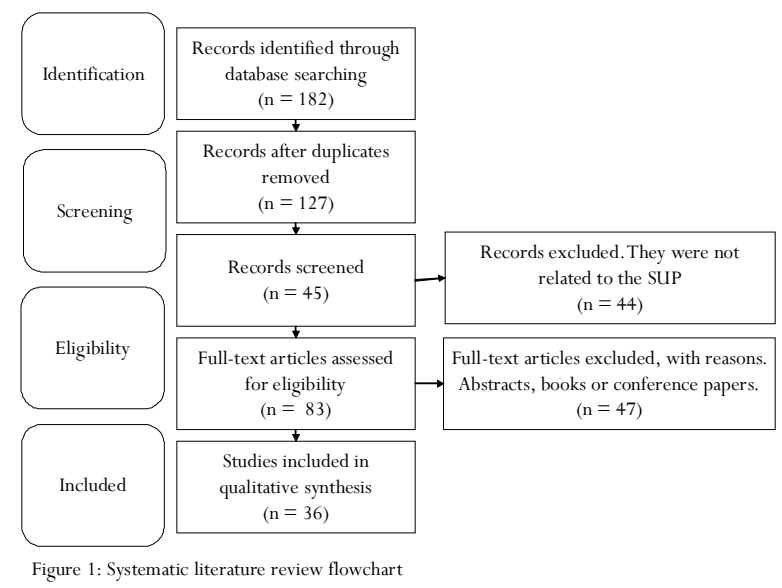

\section{Discussion}

The main objective of this review is to showcase published studies on SUP, thus showing possible future lines of research. The number of publications addressing SUP- related aspects is relatively low, especially if we consider the rapid growth of this sport in recent years. 36 articles were finally included in the systematic review, 
Table

\begin{tabular}{|c|c|c|c|c|c|}
\hline Reference & Títle & Journal & Area & Topic & Affiliation main author \\
\hline $\begin{array}{l}\text { (Balikian et al., } \\
\text { 2020) }\end{array}$ & $\begin{array}{l}\text { Anaerobic Threshold in Stand-up Paddle } \\
\text { Boarding: Comparison Between Direct and } \\
\text { Alternative Methods }\end{array}$ & $\begin{array}{l}\text { The Journal of Strength and } \\
\text { conditioning research }\end{array}$ & ysiology & $\begin{array}{l}\text { Performance. Test to determine } \\
\text { OBLA in water }\end{array}$ & $\begin{array}{l}\text { Group of Studies in Sports Training-GETE, Institute of Physical } \\
\text { Education and Sports-IEFE, Federal University of Alagoas, Macei } \\
\text { o, Brazil; }\end{array}$ \\
\hline (Bryce, 2021) & $\begin{array}{l}\text { Insight into the development and competitiveness } \\
\text { of male UK-based Stand-Up Paddleboard } \\
\text { flatwater distance racing from } 2013 \text { to } 2017\end{array}$ & $\begin{array}{l}\text { Journal of strength and conditioning } \\
\text { reserach }\end{array}$ & Physiology & $\begin{array}{l}\text { Performance. Changes in } \\
\text { competitions in the last few years }\end{array}$ & $\begin{array}{c}\text { Faculty of Science \& Technology, Bournemouth University, Poole, } \\
\text { United Kingdom }\end{array}$ \\
\hline $\begin{array}{l}\text { (Burgess et al., } \\
\text { 2019) }\end{array}$ & $\begin{array}{l}\text { Training, Diet and Supplement Regimen of an } \\
\text { Elite Female Stand- up Paddler in Preparation for } \\
\text { an Ultra-distance Event: a Case Study }\end{array}$ & $\begin{array}{l}\text { Internet journal of allied health } \\
\text { science and practice }\end{array}$ & Physiology & Performance.Training and diet & Concordia University, River Forest Illinois \\
\hline $\begin{array}{l}\text { (Caetano et al., } \\
\text { 2018) }\end{array}$ & $\begin{array}{l}\text { Altera?ôes na composi?ão corporal a partir da } \\
\text { práctica do Stand Up Paddle }\end{array}$ & $\begin{array}{c}\text { Revista Brasileira de } \mathrm{N} \\
\text { Esportiva }\end{array}$ & Physiology & Health. Changes in body composition & Estácio de Sá, Rio de Janeiro RJ, Brasil. \\
\hline $\begin{array}{l}\text { (Castañeda-Babarro } \\
\text { et al., 2020) }\end{array}$ & $\begin{array}{l}\text { Anthropometric profile, body composition, and } \\
\text { somatotype in stand-up paddle (SuP) boarding } \\
\text { international athletes: a cross-sectional study }\end{array}$ & Nutrición Hospitalaria & Physiology & $\begin{array}{l}\text { Performance. Anthropometric profile } \\
\text { of elite paddlers }\end{array}$ & $\begin{array}{l}\text { Health, Physical Activity and Sports Science Laboratory. } \\
\text { Department of Physical Activity and Sports. Faculty of Psycholog. } \\
\text { and Education. Universidad de Deusto. Bizkaia, Spain. }\end{array}$ \\
\hline $\begin{array}{l}\text { (Castañeda-Babarro } \\
\text { et al., 2020) }\end{array}$ & $\begin{array}{l}\text { The Effect of Different Cadence on Paddling } \\
\text { Gross Efficiency and Economy in Stand-UP } \\
\text { Paddle Boarding }\end{array}$ & $\begin{array}{l}\text { International Journal of } \\
\text { environmental research and public } \\
\text { health }\end{array}$ & Physiology & Performance.Energy efficiency & $\begin{array}{l}\text { Health, Physical Activity and Sports Science Laboratory, } \\
\text { Department of Physical Activity and Sports, Faculty of Psychology } \\
\text { and Education, University of Deusto, Bizkaia, Spain }\end{array}$ \\
\hline (Neiva et al, , 2021) & $\begin{array}{l}\text { A 30-min test applied to stand-up } \\
\text { paddleboarding: A pilot study }\end{array}$ & Journal of Human Sport and Exercise & hysiology & $\begin{array}{c}\text { Performance. Physiological and } \\
\text { biomechanical variables in a 30- } \\
\text { minute test }\end{array}$ & $\begin{array}{l}\text { Department of Sport Sciences, University of Beira Interior, } \\
\text { Covilhã, Portugal }\end{array}$ \\
\hline (Osti et al., (2018) & $\begin{array}{l}\text { Improvement of Balance Stability in Older } \\
\text { Individuals by On-Water Training }\end{array}$ & Journal of Aging and Physical Activity & Physiology & $\begin{array}{l}\text { Health. Cardiovascular balance and } \\
\text { function }\end{array}$ & $\begin{array}{l}\text { Human Motor Systems Laboratory, School of Physical Education } \\
\text { and Sport, University of São Paulo, Brazil }\end{array}$ \\
\hline (Roduit et al., 2017) & $\begin{array}{l}\text { Balance training with Stand-Up Paddle Boarding } \\
\text { in the elderly: data analysis }\end{array}$ & $\begin{array}{c}\text { Revista de Inovação, Tecnologia e } \\
\text { Ciências }\end{array}$ & Physiology & Health. Postural control & $\begin{array}{l}\text { Graduando do curso de Fisioterapia da Faculdade de Tecnologia e } \\
\text { Ciência, Bolsista PIBIC/FTC }\end{array}$ \\
\hline (Schram et al., 2014) & Profiling elite Stand-Up Paddle boarders & Journal of fitness research & Physiology & $\begin{array}{l}\text { Performance. Trunk musculature in } \\
\text { elite paddlers }\end{array}$ & $\begin{array}{c}\text { School of Physiotherapy, Faculty of H } \\
\text { Bond University, Gold Coast, }\end{array}$ \\
\hline (Schram et al, , 2015) & Profiling the sport of stand-up paddle boarding & Journal of Sports Sciences & Physiology & $\begin{array}{l}\text { Performance. Physiological profile of } \\
\text { the elite paddlers }\end{array}$ & $\begin{array}{l}\text { Water Based Research Unit, Bond Institute of Health \& Sport, } \\
\text { Faculty of Health Sciences and Medicine, Bond University. Gold } \\
\text { Coast, Qld }\end{array}$ \\
\hline $\begin{array}{l}\text { (Schram et al., } \\
\text { 2016a) }\end{array}$ & $\begin{array}{l}\text { Laboratory-and field-based assessment of } \\
\text { maximal aerobic power of elite Stand Up Paddle } \\
\text { board athletes }\end{array}$ & $\begin{array}{l}\text { International Journal of Sports } \\
\text { Physiology and Performance }\end{array}$ & Physiology & $\begin{array}{l}\text { Health. Improvements in several } \\
\text { health-related parameters }\end{array}$ & $\begin{array}{l}\text { Water Based Research Unit, Bond Institute of Health \& Sport, } \\
\text { Faculty of Health Sciences and Medicine, Bond University. Gold } \\
\text { Coast, Qld }\end{array}$ \\
\hline $\begin{array}{l}\text { (Schram et al., } \\
\text { 2016b) }\end{array}$ & $\begin{array}{l}\text { The physiological, musculoskeletal and } \\
\text { psychological effects of stand-up paddle boarding }\end{array}$ & $\begin{array}{l}\text { BMC Sports Science, Medicine and } \\
\text { Rehabilitation }\end{array}$ & Physiology & Performance. Maximal oxygen uptake & $\begin{array}{l}\text { Water Based Research Unit, Bond Institute of Health \& Sport, } \\
\text { e Faculty of Health Sciences and Medicine, Bond University. Gold } \\
\text { Coast, Qld }\end{array}$ \\
\hline (Schram et al., 2017) & $\begin{array}{l}\text { A performance analysis of a Stand-Up Paddle } \\
\text { Board marathon race }\end{array}$ & $\begin{array}{l}\text { Journal of Strength and Conditioning } \\
\text { Research }\end{array}$ & Physiology & $\begin{array}{l}\text { Health. Improvements in several } \\
\text { health-related parameters }\end{array}$ & $\begin{array}{l}\text { Water Based Research Unit, Bond Institute of Health \& Sport, } \\
\text { Faculty of Health Sciences and Medicine, Bond University. Gold } \\
\text { Coast, Qld }\end{array}$ \\
\hline $\begin{array}{l}\text { (Schram et al., } \\
2017 \mathrm{a})\end{array}$ & $\begin{array}{l}\text { The Long-Term Effects of Stand-up Paddle } \\
\text { Boarding: A Case Study }\end{array}$ & $\begin{array}{l}\text { International Journal of Sports and } \\
\text { Exercise Medicine }\end{array}$ & Physiology & $\begin{array}{l}\text { Health. Improvement in physiological } \\
\text { variables }\end{array}$ & $\begin{array}{l}1 \text { Water Based Research Unit, Bond Institute of Health \& Sport, } \\
\text { Bond University, Australia }\end{array}$ \\
\hline (Suari et al., 2018) & $\begin{array}{c}\text { The Effect of Environmental Conditions on the } \\
\text { Physiological Response during a Stand-Up Paddle } \\
\text { Surfing Session }\end{array}$ & Sport & Physiology & $\begin{array}{c}\text { Performance. Effect of environmental } \\
\text { conditions on physiological variables } \\
\text { in SUP surfing }\end{array}$ & $\begin{array}{l}\text { School of Marine Sciences, Ruppin Academic Center, Michmoret, } \\
\text { Israel }\end{array}$ \\
\hline $\begin{array}{l}\text { (Willmott et al., } \\
\text { 2020) }\end{array}$ & $\begin{array}{l}\text { The physiological and perceptual responses of } \\
\text { stand-up paddle board exercise in a laboratory- } \\
\text { and field-setting }\end{array}$ & European Journal of Sport Sciences & Physiology & Health. Healthy paddling intensity & $\begin{array}{c}\text { Environmental Extremes Laboratory, University of Brighton, } \\
\text { Eastbourne, UK }\end{array}$ \\
\hline (Chen et al., 2018) & $\begin{array}{c}\text { Stability of coupled human and stand-up paddle } \\
\text { board }\end{array}$ & Sports Engineering & Biomechanics & Study of the stability of the paddler & $\begin{array}{l}\text { Department of Mechanical Engineering and Material } \\
\text { Science, Duke University, Durham, USA }\end{array}$ \\
\hline (Dyer, 2018) & $\begin{array}{l}\text { A Proposed Field Assessment Method for Stand- } \\
\text { up Paddle Board Technology }\end{array}$ & $\begin{array}{l}\text { Journal of Engineering and Applied } \\
\text { Sciences }\end{array}$ & Biomechanics & Comparison of different SUP boards & $\begin{array}{c}\text { School of DEC, Bournemouth University, Fern Barrow, Poole, } \\
\text { England }\end{array}$ \\
\hline $\begin{array}{l}\text { (Praxedes et al., } \\
\text { 2019) }\end{array}$ & $\begin{array}{l}\text { Biokinematics analysis of stand up paddle ride } \\
\text { row: a study proposal }\end{array}$ & Archives of Sport Sciences & Biomechanics & $\begin{array}{l}\text { Analysed the technical gesture of the } \\
\text { paddle }\end{array}$ & $\begin{array}{l}\text { Laboratório de Biomecânica e Comportamento Motor, Instituto } \\
\text { de Educação Física e Desportos, Universidade do Estado do Rio } \\
\text { de Janeiro, Brasil }\end{array}$ \\
\hline (Schram et al,, 2019) & $\begin{array}{c}\text { A biomechanical analysis of the stand-up paddle } \\
\text { board stroke: a comparative study }\end{array}$ & PeerJ & Biomechanics & Paddlers kinematics & $\begin{array}{c}\text { Water Based Research Unit, Bond Institute of Health and Sport, } \\
\text { Bond University, Robina, QLD, } \\
\text { Australia }\end{array}$ \\
\hline (Tsai et al., 2020) & $\begin{array}{l}\text { Electromyography Analysis of Muscle Activation } \\
\text { During Stand-Up Paddle Boarding: A } \\
\text { Comparison of Paddling in Kneeling and } \\
\text { Standing Positions }\end{array}$ & Applied Sciences & Biomechanics & Paddlers muscle activation & $\begin{array}{c}\text { Center for Physical and Health Education, National Sun Yat-Sen } \\
\text { University, Kaohsiung, Taiwan; }\end{array}$ \\
\hline $\begin{array}{l}\text { (Castañeda-Babarro } \\
\text { et al., 2021) }\end{array}$ & $\begin{array}{l}\text { Relationship between Training Factors and } \\
\text { Injuries in Stand-Up Paddleboarding Athletes }\end{array}$ & $\begin{array}{l}\text { International Journal of } \\
\text { environmental research and public } \\
\text { health }\end{array}$ & Lesionability & $\begin{array}{l}\text { Injuries and their relationship with } \\
\text { training factors }\end{array}$ & $\begin{array}{l}\text { Health, Physical Activity and Sports Science Laboratory, } \\
\text { Department of Physical Activity and Sports, Faculty of Psycholog. } \\
\text { and Education, University of Deusto, Bizkaia, Spain; }\end{array}$ \\
\hline $\begin{array}{l}\text { (Furness et al., } \\
\text { 2017) }\end{array}$ & $\begin{array}{l}\text { Epidemiology of Injuries in Stand-Up } \\
\text { Paddle Boarding }\end{array}$ & $\begin{array}{l}\text { The Orthopaedic Journal of Sports } \\
\text { Medicine }\end{array}$ & Lesionability & Epidemiology of SUP injuries & $\begin{array}{c}\text { Bond Institute of Health \& Sport, Bond University, Robina, } \\
\text { Queens- } \\
\text { land, Australia }\end{array}$ \\
\hline (Griffin et al, , 2018) & Musculoskeletal Injury in Paddle Sport Athletes & Clin Journal Sport Med & Lesionability & Epidemiology of SUP injuries & $\begin{array}{l}\text { Trauma and Orthopaedic Research Unit, College of Health and } \\
\text { Medicine, } \\
\text { Australian National University, Canberra, Australia; }\end{array}$ \\
\hline $\begin{array}{c}\text { (Klontzas et al., } \\
\text { 2015) }\end{array}$ & $\begin{array}{l}\text { Imaging findings in a case of stand-up paddle } \\
\text { surfer's myelopathy }\end{array}$ & BJR Case Rep & Lesionability & Case report. Myelopathy of a paddler & $\begin{array}{l}\text { Department of Medical Imaging, University Hospital of } \\
\text { Heraklion, University of Crete, Heraklion-Crete, Greece }\end{array}$ \\
\hline (Spittler et al, , 2020) & $\begin{array}{l}\text { Common Injuries in Whitewater Rafting, } \\
\text { Kayaking, Canoeing, and Stand-Up Paddle } \\
\text { Boarding }\end{array}$ & Sports Specific illnes and injury & Lesionability & Epidemiology of paddle sports & $\begin{array}{l}\text { Departments of Family Medicine and Orthopedics, University o } \\
\text { Colorado, Aurora, CO. }\end{array}$ \\
\hline $\begin{array}{c}\text { (Waydia \& } \\
\text { Woodacre, 2016) }\end{array}$ & $\begin{array}{l}\text { Paddle-boarding: Fun, New Sport or an Accident } \\
\text { Waiting to Happen? }\end{array}$ & Trauma Mon & Lesionability & Epidemiology of SUP injuries & $\begin{array}{l}\text { Department of Trauma and Orthopaedics, Royal Cornwall } \\
\text { Hospital, Truro, Cornwall, UK }\end{array}$ \\
\hline $\begin{array}{l}\text { (Cardoso \& Campos, } \\
\text { 2018) }\end{array}$ & $\begin{array}{c}\text { Surfing and non-formal education: power and } \\
\text { practice in the social project "surfing and Satnd } \\
\text { Paddle for all" }\end{array}$ & Journal of Olympic Studies & Education & Educational potential of surfing & $\begin{array}{l}\text { Escola de Educação Física e Esporte Universidade de São Paulo, } \\
\qquad \text { Brasil }\end{array}$ \\
\hline (Serra et al., 2020) & $\begin{array}{l}\text { A board made of plastic botlles: a functional, } \\
\text { ecologic and economic alternative for learning } \\
\text { stand-up paddle boarding }\end{array}$ & Physical Education and Sport & Education & $\begin{array}{l}\text { Educational proposal with a board } \\
\text { made of plastic bottles }\end{array}$ & $\begin{array}{l}\text { School of Physical Education and Sport, Federal University of Sã } \\
\text { Paulo, São Paulo, Brazil }\end{array}$ \\
\hline (Zagare, 2015) & $\begin{array}{l}\text { Lecture adapted from Stand Up Paddle Boarding } \\
\text { with pet bottles in physical education classes }\end{array}$ & $\begin{array}{l}\text { Revista de Gestão e Avaliação } \\
\text { Educacional }\end{array}$ & Education & $\begin{array}{l}\text { Adapting SUP to an educational } \\
\text { approach }\end{array}$ & Escola Estadual Chiquinha Rodrigues, Brasil \\
\hline $\begin{array}{l}\text { (Azevedo et al., } \\
\text { 2017) }\end{array}$ & $\begin{array}{c}\text { Stand Up Paddle Boarding and environmental } \\
\text { awareness }\end{array}$ & Revista Carioca de Educa?ao Física & Other & SUP practice as an adventure sport & Centro Universitário Augusto Motta, Rio de Janeiro - RJ - Brasil \\
\hline $\begin{array}{l}\text { (Bartmann et al., } \\
\text { 2019) }\end{array}$ & Quais as novidades no stand up paddle? & $\begin{array}{l}\text { Ciência em Movimento Biociências e } \\
\text { Saúde }\end{array}$ & Other & Sup Review & $\begin{array}{l}\text { Mestrando do Programa de Pós-Graduação em Biociências e } \\
\text { Reabilitação. Centro Universitário Metodista - IPA e Professor } \\
\text { da Faculdade Sogipa. Porto Alegre - RS. }\end{array}$ \\
\hline (Novak, 2021) & $\begin{array}{l}\text { A Parametric Method to Customize Surfboard } \\
\text { and Stand Up Paddle Board Fins for Additive } \\
\text { Manufacturing }\end{array}$ & $\begin{array}{l}\text { Computer-Aided Design \& } \\
\text { Applications }\end{array}$ & Other & Produce SUP board fins by 3D & Deakin University, Australia \\
\hline $\begin{array}{l}\text { (Palacios-Aguilar et } \\
\text { al., 2018) }\end{array}$ & $\begin{array}{l}\text { Air Stand-up Paddle water rescue table: How can } \\
\text { it help to the lifegurd? }\end{array}$ & Rev.,int.med.cienc.act.fis.deporte & Other & Inflatable SUP board for lifeguards & $\begin{array}{c}\text { Facultad de Ciencias del Deporte y la Educación Física. } \\
\text { Universidad de A Coruña. A Coruña }\end{array}$ \\
\hline $\begin{array}{l}\text { (Schram \& Furness, } \\
\text { 2017) }\end{array}$ & $\begin{array}{l}\text { Exploring the Utilisation of Stand up Paddle } \\
\text { Boarding in Australia }\end{array}$ & Sport & Other & Motivations for SUP practice & $\begin{array}{l}\text { Water Based Research Unit, Bond Institute of Health \& Sport, } \\
\text { Faculty of Health Sciences and Medicine, Bond University, Gold }\end{array}$ \\
\hline
\end{tabular}


and a thematic discussion of those articles is presented below.

\section{Physiology}

Most of the research related to health in SUP has focused on analysing the physiological adaptations made by the practice in the medium and long term (Osti, de Souza \& Teixeira, 2018; Schram, Hing \& Climstein, 2016b; Schram, Hing \& Climstein, 2017a; Schram, Hing, Climstein \& Furness, 2017b). For example, Caetano, Colodetti, de Souza, de Carvalho, Guimarães \& de Farias (2018) analysed the changes in body composition of two sedentary subjects (a man and a woman) after they had practised SUP for 8 weeks, recording improvements in the subjects' body composition variables and concluding that SUP can be used as a physical activity beneficial to health.

Schram et al. (2016b), in a similar approach, analysed changes in various health parameters in 13 untrained participants ( 9 men and 4 women) during 6 weeks of SUP practice (3 days, 1 hour per day). The cardiovascular, musculoskeletal and psychological improvements that beginners can achieve when using SUP as a training tool corroborate the health and fitness benefits of SUP. The results obtained by Schram et al. (Schram et al., 2017a) with two middle-aged subjects (one male and one female) over one year are in line with the two previous studies, namely, improvements in: body composition, aerobic fitness, trunk muscular endurance and self-rated quality of life.

In order to quantify the physiological and perceptual responses of SUP exercise in a laboratory and field setting, Willmott, Sayers \& Brickley (2020) tested 10 subjects ( 8 men and 2 women) at different cadences (10-20 and 30 paddles per minute) both in the laboratory and in the field. By measuring energy expenditure, metabolic equivalents, heart rate and perceived exertion, they concluded that SUP at e» 20 paddles.min${ }^{1}$ in laboratory and field conditions meets the criteria for moderate-intensity exercise (3.0-5.9 METs).

Furthermore, Schram, Hing \& Climstein (2015) studied anthropometric, physiological and musculoskeletal differences among 30 paddlers (15 elite and 15 recreational) and 15 sedentary subjects as a control group, concluding that the elite paddlers had lower body fat, higher maximal oxygen consumption and significantly better postural control than the recreational paddler group. Along these lines, Schram, Hing, Climstein \&Walsh (2014) evaluated the multifidus cross-section, postural control and an isometric lumbar extension test among 8 elite paddlers compared to population mean values. The results demonstrated how SUP can be beneficial to strength and endurance training of the trunk musculature and to balance training. Along the same lines are the conclusions from the study by Osti et al. (2018) and Roduit, Lacerda \& Maia (2017), in which the effect of SUP practice on vertical postural control (balance) in the first case, and balance, pain and cardiovascular function in the second case, was evaluated in elderly individuals. The intervention carried out by the exercise programme showed that SUP appears to be an effective medium-term method for balance training and reduction of back pain, although there were no significant changes in blood pressure.

Various studies have been carried out that focus on the research carried out on elite paddlers or with the aim of improving the performance of these athletes, some of them with a view to understanding the physiological demands required by the participants. A performance analysis of a SUP board marathon race was conducted, in which the performance of 10 elite paddlers (6 men and 4 women) was analysed. In the course of this analysis it was observed how, in addition to variations in the distance covered by participants $(13.3 \mathrm{~km}-13.9 \mathrm{~km})$, they spent $89.3 \%$ of the race at between 80 and $100 \%$ of their maximum heart rate predicted for their age, demonstrating a high aerobic requirement (Schram et al., 2017b). Bryce (2021), on the other hand, conducted an analysis of 2 SUP events from different years, to research into any changes in their participation or race behaviour, and as to whether such events should be approached differently by practitioners, concluding that the events did not change significantly in their range of completion times between paddlers from year to year when looking at 3 subgroups and that the events may warrant different training methodologies and tactical decision making.

Seeking to learn more about the physical capabilities of elite paddlers, Schram et al. (2016a) conducted a laboratory and in-water maximal oxygen uptake test on 10 elite athletes, obtaining a close correlation between laboratory and field measurements and ascertaining that elite SUP athletes showed similar aerobic power performances to other elite athletes with upper limb dominance in water (surfing, dragon boat racing and canoeing).

In order to improve elite paddlers' preparation, Neiva, Faíl \& Marinho (2021) conducted a case study on an experienced male paddler who performed a 30-min maximal test in order to analyse physiological and 
biomechanical variables. Significant relationships were observed between speed and distance per stroke, and it was found that the 30-minute test represented an intensity of around $85 \%$ of maximum HR. For their part, Balikian, Marinho, Gomes de Araujo, Prado, Mendes \& Ryan Geraldes (2020) studied the validity of alternative protocols and average speed of 8 paddlers over 30 minutes of continuous effort and critical speed (progressive intensities test), to estimate anaerobic threshold in the water. They concluded that both critical speed and the 30-minute continuous test are valid for the purpose of estimating OBLA.

Related to the previous performance determinant variable that is OBLA, Castañeda-Babarro, Santosconcejero \& Viribay (2020a) studied the physiological response (efficiency, economy, lactate concentration, HR...) of paddling at $75 \%$ of power generated at maximum oxygen consumption at three different cadences (45-55 and 65 strokes-min ${ }^{-1}$ ) in 10 international paddlers. They showed how paddlers were more efficient and performed more economically when paddling at 45 strokes per minute (spm) versus 55 or $65 \mathrm{spm}$, as confirmed by lower RPE values.

Other important aspects are those studied by Castañeda-Babarro, Viribay-Morales, León-Guereño, Urdanpilleta-Otegui, Mielgo-Ayuso \& Coca (2020b) which described the anthropometric profile of international paddlers. 31 paddlers were assessed to conclude that these athletes have a balanced mesomorphic somatotype, low fat percentage and high muscle mass, and that a low fold sum and high arm muscle mass may be key factors in performance in this sport.

As for anthropometrics and referring to the only study related to nutrition in these athletes, Burgess, Bommarito \& Antonio (2019) conducted a study with the aim of examining the training, diet and supplement regime of an elite female paddler in preparation for an ultra-distance SUP race. The nutritional strategies undertaken included an increase in daily protein intake, as well as supplementation with beta-hydroxy methyl butyrate HMB and beta-alanine. Together, these strategies resulted in a $3.16 \mathrm{~kg}$ increase in body mass and a $2 \%$ decrease in body fat.

Finally, and in reference to the only research related to SUP surfing. Suari, Schram, Ashkenazi, Gann-Perkal, Berger, Reznikov, Shomrat \& Kodesh (2018) studied the physiological response to SUP sessions and determined how various environmental conditions may influence this response. The results highlight aerobic fitness in SUP surfing and demonstrate that environmental conditions may have an effect on physiological response during these sessions.

Therefore, we can summarize that the main physiological outcomes related with SUP performance and health, are connected with athletes' body composition, showing low fat percentage and high muscle mass, trunk muscular endurance, a high aerobic requirements.

\section{Biomechanics}

Of the five articles related to biomechanics found, two of them study the kinematics of the SUP paddle stroke. On the one hand, in the first research conducted by Schram, Furness, Kemp-Smith, Sharp, Cristini, Harvie, Keady, Ghobrial, Tussler, Hing, Nessler \& Becker (2019), the kinematics between experienced (7 subjects) and non-experienced (19 subjects) paddlers was compared, finding significant differences in the shoulder, elbow and hip. On the other, Praxedes et al. (2019), analysed the technical gesture of the paddle (upper limbs) in two experienced subjects with the intention of looking for similarities in the technical gesture. In so doing, they found a similar movement in the shoulder, but not so in the elbow.

In order to understand individual muscle use in different (kneeling and standing) SUP paddle boarding postures, Tsai, Wu, Chen, Liang \& Hou (2020) recorded surface electromyography of 16 muscles on the dominant side in 16 university students. The results showed a very different activation of the biceps in the two types studied, both in terms of activation patterns and intensity (greater kneeling), as well as greater activation of the external oblique and triceps in standing while paddling.

Dyer (2018) conducted a study with the aim of assessing the intra-test reliability of a proposed field assessment methodology with different levels of sup technology (change made to the board, paddle or finding and assessing its performance and statistical reliability). The method employed yielded a good level of reliability in all three tests performed.

Finally, there is the study by Chen, Sequeira \& Mann (2018) which researches into paddler stability as a function of board dimensions, rider body parameters and skill level, using a floating body dynamics approach. Results show that the eigenvalue contours match the qualitative terms, such as beginner and professional.

\section{Lesionability}

Injury aetiology is a multifaceted process, and to try to lower or avoid severe injuries is crucial in sports 
(Colonna et al., 2022). In their review, Spittler, Gillum \& DeSanto (2020) describe the epidemiology, type and location of injuries in paddle sports. They explain how injuries vary depending on the aquatic environment, sport, skill level and competitive level (competition vs. recreation), and comment on the need for further research in order to learn more about SUP injuries.

There are three articles that delve a little deeper into the amount, type and other characteristics of SUP injuries. The first of these is by Waydia \& Woodacre (2016), who reported epidemiological characteristics of SUP surfing injuries. Half of the injuries were sprains and $78 \%$ of the injuries were to the lower body, with the vast majority of injuries being caused by contact with the board itself or by contact with another SUP board.

Regarding SUP racing, both Furness, Olorunnife, Schram, Climstein \& Hing (2017) and Griffin, Perriman, Neeman \& Smith (2018) report a higher frequency of injury to the shoulders, lower back and elbows, as well as to the wrist and neck. Muscle/tendon injuries were the most common, with older age, competitor status and longer hours' practice being the most important variables influencing the likelihood of injury. An injury rate of 3.63 per 1000 hours of SUP was reported in the case of SUP.

Klontzas, Hatzidakis \& Karantanas (2015), present a case study, specifically, the first case of a 28 year-old athlete who developed myelopathy during his first SUP surfing session. Clinical examination revealed a severe neurological deficit, which had not fully subsided at the 28-month follow-up.

The only article that studies variables that can prevent SUP injuries is the research carried out by CastañedaBabarro, Calleja-González, Viribay, Fernández-Lázaro, León-Guereño \& Mielgo-Ayuso (2021), in which they found a relationship between the probability of suffering an injury the less strength training was carried out (per week and per year), irrespective of whether this strength training was carried out in isolation or together with CORE or flexibility training.

\section{Education field}

Perhaps because of the major appeal of this activity or because of its low technical difficulty, and also taking into account the few publications on this sport, despite the importance of pedagogical orientation and application in formal education (Pérez-Gutiérrez, Castanedo-Alonso \& Cobo-Corrales, 2021), there are only 3 proposals aimed at the education field.
The first of these is a proposal by Zagare (2015) which aims to show how physical education classes can be adapted to SUP. It proposes practising it with some adaptations such as the plastic bottle board, the broomstick paddle or the curtain bar with a tennis ball at the end, which facilitates the teaching of SUP. Its practice also brings an awareness of the environment, since this proposal involves reusing materials.

Related to the above, Serra, Placencia, Henrique \& Rodrigures (2020) conducted research with the main objective of determining whether the use of the alternative board made of plastic bottles compared to the conventional board affects the learning and practice of SUP. After comparing the use of these boards with conventional boards on 16 healthy subjects, it was concluded that the recycled board was as functional as a conventional board, but cheaper and less harmful to the environment.

Finally, and with the aim of observing the possibility and relevance of developing elements of non-formal education related to SUP in the surfing environment in leisure and performance sports structures, Cardoso \& Campos (2018) analyse biographical narratives of the coach/teacher and student. They suggest that the practice of SUP surfing offers potential beyond the sporting dimension in terms of high performance, because it can also be approached as a pedagogical tool and a space for social interaction, allowing its practitioners moments that can bring together pleasure, learning and body excellence in movement in its various forms of practice - leisure, health and competitive and professional quality of life.

\section{Other issues}

In this section, the intention has been to include articles whose subject matter does not fit in the other sections, such as a review, albeit with many limitations, carried out by Bartmann, Ribeiro, Pochmann \& Cláudia (2019) on the articles published in Pubmed on this subject up to 2018, with 8 articles being found in total ( 2 on injuries, 2 on the physiology of exercise, 2 on posture and 2 on body composition).

Additionally, two publications study the way in which SUP is practised. On the one hand, Azevedo, Carvalho, Batista \& Columá (2017) aim to discuss, via a review, the relationship of SUP practice as an adventure sport, concluding that this form of adventure has become a growing practice, especially in coastal regions. On the other, Schram and Furness (2017c) conducted a study via an on-line questionnaire, with the aim of finding out 
more about how and where people practise SUP. They concluded that participants most commonly used SUP for fun and fitness for around 3 hours a week, predominantly at the beach with friends, with around half of respondents reporting competitive participation.

Finally, two other SUP-related publications have been noted, one by Novak (2021) which examines the opportunity to produce SUP board fins by 3D printing and details a parametric computer-aided design (CAD) system for surfers to modify the geometry of a surfboard fin in real time: The other is by Palacios-Aguilar, BarcalaFurelos, López-García, Carpentier \& Abelairas-Gómez (2018) who conducted research on 16 professional lifeguards, with the aim of analysing the effect of using the Airsupra board (inflatable SUP board) on approach time over a distance of $100 \mathrm{~m}$, obtaining significantly better results than the approach without a board.

\section{Conclusion}

SUP is an activity or sport practice related to leisure, maintenance of physical shape and competitive practice, with a great potential in different fields. As far as health is concerned, SUP improves cardiovascular (aerobic fitness), musculoskeletal (especially in the trunk musculature), psychological (quality of life) and body composition, and it can be affirmed that SUP helps to improve the health of those who practise it. As far as competitive SUP is concerned, lower percentages of body fat, higher maximum oxygen consumption, greater postural control/development of trunk muscles and balance have been recorded in elite paddlers than in the normal population or amateur practitioners. Similarly, in order to perform successfully, it is necessary to have a good aerobic fitness (similar to other modalities in the water with upper limb dominance), a balanced mesomorphic somatotype, low percentage of fat and high muscle mass, as well as controlling the cadence of the stroke with the aim of improving efficiency (45rpm).

On the other hand, the kinematic variability and muscle activation recorded when performing the technical gesture, both in inexperienced and experienced SUP athletes, makes it difficult to understand the biomechanics of the activity. Despite this, it seems clear that SUP surfing has a higher probability of injury to the lower limbs, with sprains being the most recorded mechanism, while SUP racing has a higher frequency of injury to the upper limbs (neck, shoulder, lower back, elbow and wrist), especially muscle/tendon injuries, and strength training is a valid strategy for the prevention of those injuries.

However, considering the few studies that exist on this type of sport, further studies are needed to learn more about its potential as a healthy and educational activity, and all the more so, given the importance given to educational field, and as some papers show, its educational potential cannot be ignored. Moreover, research is needed also about its physiological requirements for competition or more correct biomechanics to help reduce injuries and improve performance.

\section{Practical Applications}

This review is intended to be an initial reference to help all athletes and professionals related to SUP manage athletes' physical preparation. Our results suggest that coaches on this field should try their paddlers to show a low-fat percentage and high muscle mass, and to develop a high aerobic capacity, to improve athletes' performance. In addition, it also provides the general public with information on a sport that has great potential for improving health and educational practice.

Since SUP related publications are very scarce, this review also reflects the possibilities for future research related to this type of sport, which could be developed in the fields of physiology (health or performance), biomechanics, injury, education and economics (SUP industry).

\section{Ethical approval information}

No Ethical Approval was necessary to present this review.

\section{Conflicts of Interest}

The authors declare no conflict of interest with any financial organisation regarding the material discussed in the manuscript.

\section{Funding}

This research received no external funding, given that is a narrative review.

\section{Author Contributions}

A.C.-B., P.L.-G. and E.B.E.: Concept and design, analysis and interpretation of data, draft version, critical review and approval of final version of the paper submitted for publication. A.C.-B., P.L.-G. and E.B.E.: Data interpretation, draft version, critical review and approval of final version of the paper submitted for 
publication. All authors have read and agreed to the published version of the manuscript.

\section{References}

Addison, C. (2010). The history of stand up paddling. «Recuperado de» https://www.supworldmag.com/the-history-of-standup-paddling/

Argyle, M. (2011). SUP Global History. «Recuperado de» http:/ / supglobal.com/stand-up-paddle-features/sup-lifestyle/thehistory-of-stand-up-paddle-surfing/

Azevedo,L.E., Carvalho, J.D., Batista,F.F., \& Columá,J.F.(2017). Stand Up Paddle e conscienciência Ambiental. Revista Carioca de Educação Física, 12(1), 52-66. «Recuperado de» https:// revistacarioca.com.br/revistacarioca/article/view/45/43

Balikian, P., Marinho,A., Gomes deAraujo, G., Prado, E., Mendes, E., \& Ryan Geraldes,A. (2020).AnaerobicThreshold in Standup Paddle: Comparison Between Direct and Alternative Methods. Journal of Strength and Conditioning Research, $O(0), 1-$ 5. «Recuperado de» https://doi.org/10.1519/ JSC.0000000000003718

Bartmann, F., Ribeiro, J. L., Pochmann, D., \& Cláudia, F. (2019). What's new in the stand up paddle/ ? Ciência Em Movimento | Biociênciase Saúde, 21(42), 93-97. «Recuperado de» https:/ /www.metodista.br/revistas/revistas-ipa/index.php/ $\mathrm{CMBS} /$ article/view/858

Beachboy, P. P. (2006). Pokaku beachboy paddles - History of beachboy surfing. «Recuperado de» https:// www.standuppaddles.com/history.shtml.

Bryce, D. (2021). Insight into the development and competitiveness of male UK-based Stand-Up Paddleboard flatwater distance racing from 2013 to 2017. Journal of Strength and Conditioning Research, 35(2), 535-541. «Recuperado de» https:// journals.lww.com/nsca-jscr/Abstract/2021 /02000/ Insight_Into_the_Development_and_Competitiveness.33.aspx

Burgess, V., Bommarito, P., \& Antonio, J. (2019). Diet and Supplement Regimen of an Elite Female Standup Paddler in Preparation for an Ultra-distance Event: a Case Study. Internet Journal of Allied Health Sciences \& Practice, 17(2), 1-8. «Recuperado de» https://search.ebscohost.com/ login.aspx?direct $=$ true\&db $={ }_{\mathrm{ccm}} \& \mathrm{AN}=135881251$ \&site $=$ ehost live

Caetano,A., Colodetti,E. B., de Souza,W.C., de Carvalho,A.B.M., Guimarães,TT., \& de Farias, E. (2018).Alteraçõesna composição corporal a partir da prática do stand up paddle. Revista Brasileira de Nutrição Esportiva, 12(71), 295-300.

Cardoso, V., \& Campos, R. (2018). Surfing and non-formal education: power and practice in the social project «surfing and Stand Up Paddle for all.» Olimpianos - Journal of Olympic Studies, 2(3), 539-554. «Recuperado de» https://doi.org/ 10.30937/2526-6314.v2n3.id60

Castañeda-babarro,A., Santos-concejero, J., \&Viribay,A. (2020a). The Effect of Different Cadence on Paddling Gross Efficiency and Economy in Stand-Up Paddle Boarding. International
Journal of Environmental Research and Public Health, 17, 4893. «Recuperado de» https://pubmed.ncbi.nlm.nih.gov/ 32645890/

Castañeda-Babarro, A.; Viribay-Morales, A.; León-Guereño, P.; Urdanpilleta-Otegui, A.; Mielgo-Ayuso, J. and Coca, A. (2020b). Anthropometric profile, body composition, and somatotype in stand-up paddle (SUP) boarding international athletes: a cross-sectional study. Nutrición Hospitalaria, 37(5), 958-963. «Recuperado de» https://scielo.isciii.es/ s c i e l o.ph p ? p i d = S 02212 $16112020000700011 \&$ script $=$ sci_abstract\&tlng $=$ en

Castañeda-Babarro,A., Calleja-González, J.,Viribay,A., FernándezLázaro, D., León-Guereño, P., \& Mielgo-Ayuso, J. (2021). Relationship between training factors and injuries in stand-up paddleboarding athletes. International Journal of Environmental Research and Public Health, 18, 880. «Recuperado de» https:/ /doi.org/10.3390/ijerph18030880

Chen, H.J., Sequeira, D., \& Mann, B. P. (2018). Stability of coupled human and stand-up paddle board. Sports Engineering, 21, 429440. «Recuperado de» https://doi.org/10.1007/s12283018-0289-7

Colonna, M., Rolim,Y.,Vale, R., de Castro, J. B. P., Nunes, R. D.A. M., Lima,V., Mallen-Silva, G.C. \& Casimiro-Lopes, G. (2022). Analysis of injuries in Judo athletes: A systematic review. Retos: nuevas tendencias en educación fisica, deporte y recreación, (43), 560-566.

Roduit, C.G., Lacerda,W.S., \& Maia,A.M.(2017). BalanceTraining with Stand Up Paddle in the elderly: analysis of data. Revista de Inovação, Tecnologia e Ciências, 2(2), 32-40.

Dyer, B. (2018). A Proposed Field Assessment Method for Standup Paddle BoardTechnology. Journal of Engineering and Applied Sciences, 13(8), 2120-2125. «Recuperado de» http:// eprints.bournemouth.ac.uk/30882/

Furness, J., Olorunnife, O., Schram, B., Climstein, M., \& Hing,W. (2017). Epidemiology of Injuries in Stand-UpPaddle Boarding. Orthopaedic Journal of Sports Medicine, 5(6), 1-9. «Recuperado de» https://doi.org/10.1177/2325967117710759

Griffin, A. R., Perriman, D. M., Neeman, T. M., \& Smith, P. N. (2018). Musculoskeletal Injury in Paddle Sport Athletes. Clinical Journal of Sport Medicine / : Official Journal of the Canadian Academy of Sport Medicine, O(0), 1-9. «Recuperado de» https:/ /doi.org/10.1097/JSM.0000000000000565

Hammer, S. (2011). Catch the wave of stand up paddling. The Providence Journal, 5(3). «Recuperado de» https:// $\mathrm{s}$ c h o l a r.g o o g l e . c o m / scholar_lookup?title $=$ Catch + the + wave + of + stand -

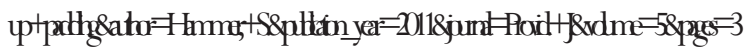

ISA. (2021). «Recuperado de» http: / /isawlc.com/es/the-first-standalone-isa-world-longboard-championship-to-take-place-thisseptember-in-peru/. http://isawlc.com/es/the-first-standalone-isa-world-longboard-championship-to-take-place-thisseptember-in-peru/

Pérez-Gutiérrez, M., Castanedo-Alonso, J.M., \& Cobo-Corrales, C. (2021). El El surf en la educación formal: revisión sistemática (Surfingin formal education: systematic review). Retos, 41, 
684-694.

Praxedes, J., Carvalho, I., Pinto, S., Neiva, D., Salles, K., Laukas, E. \& Cortines, S., (2019). Análise biocinemática da remada de passeio do stand up paddle: uma proposta de estudo. Arquivos de Ciências Do Esporte, 7(2), 96-99. «Recuperado de» http:// seer.uftm.edu.br/revistaeletronica/index.php/aces/article/ view/3746

Klontzas, M.E., Hatzidakis,A., \& Karantanas,A.H. (2015). Imaging findings in a case of stand up paddle surfer's myelopathy. BJR | case Reports, 1, 20150004. «Recuperado de» https://doi.org/ 10.1259/bjrcr.20150004

Moher D., Liberati A., Tetzlaff J., Altman D.G. \& The PRISMA Group (2009) Preferred Reporting Items for Systematic Reviews and Meta-Analyses: The PRISMA Statement. PLoS Medicine, 6(7). «Recuperado de» doi:10.1371/ journal.pmed.1000097

Neiva, H. P., Fail, L. B., \& Marinho, D. A. (2021). A 30-min test applied to stand-up paddleboarding: A pilot study. Journal of Human Sport \& Exercise, 15, 1387. «Recuperado de» https: / / doi.org/10.14198/jhse.2020.15.proc4.35

Novak, J. I. (2021). A parametric method to customize surfboard and stand up paddle board fins for additive manufacturing. Computer-Aided Design and Applications, 18(2), 297-308. «Recuperado de» https: / / doi.org/10.14733/cadaps.2021.297308

Osti, F. R., de Souza, C. R., \&Teixeira, L.A. (2018). Improvement of Balance Stability in Older Individuals by On-Water Training. Journal of aging and physical activity, 26(2), 222-226.

Palacios-Aguilar, J., Barcala-Furelos, R., López-García, S., Carpentier,M., \&Abelairas-Gómez, C. (2018).AirTable StandUp PaddleWater Rescue: How CanYou HelpThe Lifeguard? Revista Internacional de Medicina y Ciencias de La Actividad Física y Del Deporte, 18(69), 185-197. https://doi.org/10.15366/ rimcafd2018.69.012

Schram, B., Hing,W., Climstein, M., \&Walsh, J. (2014). Profiling elite stand up paddle boarders. Journal of Fitness Research, 3(1), 40-51. «Recuperado de» http:/ / fitnessresearch.edu.au/ journal-view/profiling-elite-stand-up-paddle-boarders-82

Schram, B. , Hing,W., \& Climstein, M. (2015). Profiling the sport of stand-up paddle boarding. Journal of Sports Sciences. «Recuperado de» https://doi.org/10.1080/ 02640414.2015.1079331

Schram, B., Hing, W., \& Climstein, M. (2016a). Laboratory-and field-based assessment of maximal aerobic power of elite standup paddle-board athletes. International Journal of Sports Physiology and Performance, 11(1), 28-32. «Recuperado de» https:// doi.org/10.1123/ijspp.2015-0076

Schram, B., Hing,W., \& Climstein, M. (2016b).The physiological, musculoskeletal and psychological effects of stand up paddle boarding. BMC Sports Science, Medicine and Rehabilitation, 8(32), 1-9. «Recuperado de» https://doi.org/10.1186/s13102016-0057-6

Schram B., Hing W. \& Climstein. M. (2017a). The Long-Term Effects of Stand-up Paddle Boarding:A Case Study. International Journal of Sports and Exercise Medicine, 3(4), 4-9. «Recuperado de» https://doi.org/10.23937/2469-5718/1510065

Schram, B., Hing, W., Climstein, M., \& Furness, J. (2017b). A performance analysis of a stand-up paddle board marathon race. Journal of Strength and Conditioning Research, 31(6), 1552 1556. «Recuperado de» https://doi.org/10.1519/ JSC.0000000000001707

Schram, B., \& Furness, J. (2017c). Exploring the Utilisation of Stand up Paddle Boarding in Australia. Sports, 5, 53. «Recuperado de» https://doi.org/10.3390/sports5030053

Schram, B., Furness, J., Kemp-Smith, K., Sharp, J., Cristini, M., Harvie, D., Keady, E., Ghobrial, M.,Tussler, J., Hing,W., Nessler, J., \& Becker, M. (2019). A biomechanical analysis of the standup paddle board stroke: A comparative study. PeerJ, 7, 8. «Recuperado de» https://doi.org/10.7717/peerj.8006

Serra,F.T., Placencia, E.V.D., Henrique, J.S., \& Rodrigures, G. D.M. (2020).A Board Made of Plastic Bottles: a Functional, Ecologic and Economic Alternative For Learning Stand Up Paddle Boarding. Physical Education and Sport, 18(1), 135-144. «Recuperado de» https://doi.org/10.22190/ FUPES200320012S

Spittler, J., Gillum, R., \& DeSanto, K. (2020). Common Injuries in Whitewater Rafting, Kayaking, Canoeing, and Stand-Up Paddle Boarding. Sports-Specific Illness and Injury, 19(10) 422-429. «Recuperado de» https://doi.org/10.1249/ jsr.0000000000000763

Stand Up Paddle Industry Association. (2014). «Recuperado de» http: / /www.supindustry.org.

Stewart LA, Clarke M, Rovers M, Riley RD, Simmonds M, Stewart G,T.J.(2015). PRISMA-IPD Development Group. Preferred Reporting Items for Systematic Review and Meta-Analyses of individual participant data: the PRISMA-IPD Statement.JAMA, 313(16), 1657-1665. «Recuperado de» https:// doi:10.1001/jama.2015.3656

Suari,Y., Schram, B., Ashkenazi, A., Gann-Perkal, H., Berger, L., Reznikov, M., Shomrat, S., \& Kodesh,E. (2018).The Effect of Environmental Conditions on the Physiological Response during a Stand-Up Paddle Surfing Session. Sports, 6(25), 1-8. «Recuperado de» https://doi.org/10.3390/sports6020025

Tsai, F. H., Wu,W. L., Chen,Y. J., Liang, J. M., \& Hou,Y.Y. (2020). Electromyography analysis of muscle activation during standup paddle boarding: A comparison of paddling in kneeling and standing positions. Applied Sciences (Switzerland), 10, 2356. «Recuperado de» https://doi.org/10.3390/app10072356

Waydia \&Woodacre (2016). Paddle-boarding: Fun, New Sport or an Accident Waiting to Happen? Trauma Mon, 21(3), 19299. https://doi.org/10.5812/traumamon.19299.Research

Willmott, A. G. B., Sayers, B., \& Brickley, G. (2020). The physiological and perceptual responses of stand-up paddle board exercise in a laboratory-and field-setting. European Journal of Sport Science, 20(8), 1023-1033. «Recuperado de» https:/ /pubmed.ncbi.nlm.nih.gov/28180114/

Zagare,T. (2015). Aula adaptada de Stand Up Paddle com garrafas pet nas aulas de educa«ão fisica. Revista de Gestão e Avaliação Educacional, 4(8), 79-95. «Recuperado de» https: / /doi.org/ $10.5902 / 2318133816975$ 